\title{
Impact of reduced tillage on soil organic carbon and nutrient budgets under organic farming
}

\author{
Florian Gadermaier $^{1,2}$, Alfred Berner ${ }^{1 \star}$, Andreas Fließbach $^{1}$, Jürgen Kurt Friedel ${ }^{2}$, \\ and Paul Mäder ${ }^{1}$ \\ ${ }^{1}$ Research Institute of Organic Agriculture, Ackerstraße, CH-5070 Frick, Switzerland. \\ ${ }^{2}$ Division of Organic Farming, Department of Sustainable Agricultural Systems, University of Natural \\ Resources and Applied Life Sciences, Gregor Mendel Strasse 33, A-1180 Vienna, Austria. \\ ${ }^{\star}$ Corresponding author: alfred.berner@fibl.org
}

Accepted 10 November 2010; First published online 12 January 2011

Research Paper

\begin{abstract}
No-tillage (NT) and reduced tillage (RT) systems are well-known management tools for reducing soil erosion and improving soil fertility. NT and RT may improve the environmental and economic performance of organic farming, but they are still not common practice among organic farmers. This paper presents the effects of tillage [RT versus conventional tillage (CT)], fertilization (slurry versus manure compost) and biodynamic preparations (with versus without) on soil fertility indicators such as soil organic carbon $\left(\mathrm{C}_{\mathrm{org}}\right)$, microbial biomass and microbial activity, soil nutrients and nutrient budgets in an organic farming system during the first six-year crop rotation period of a long-term experiment on a clayey soil in a temperate climate. RT caused stratification of soil organic carbon $\left(\mathrm{C}_{\mathrm{org}}\right)$, microbial properties and soil nutrients in the soil profile. Under RT, $C_{\text {org }}$ in the $0-10 \mathrm{~cm}$ soil layer increased from 2.19 to $2.61 \%$ (w/w) from 2002 to 2008, whereas it remained constant under $\mathrm{CT}$. In both tillage treatments, $\mathrm{C}_{\text {org }}$ remained constant in the $10-20 \mathrm{~cm}$ soil depth. Microbial biomass $\mathrm{C}$ increased by $37 \%$ under RT in the $0-10 \mathrm{~cm}$ soil depth and microbial activity [dehydrogenase activity (DHA)] was enhanced by $57 \%$. Soil microbial biomass $\mathrm{C}$ and DHA in the $10-20 \mathrm{~cm}$ soil depth were also higher under RT (+ 10 and $+17 \%$, respectively). Soluble soil P and K were 72 and 40\%, respectively, higher in 0-10 cm soil depth under RT when compared with CT. Fertilization showed no effects on the measured soil properties. Biodynamic preparations increased solely the $\mathrm{C}_{\text {mic }}$-to- $\mathrm{N}_{\text {mic }}$ (soil microbial biomass $\mathrm{C}$ to soil microbial biomass $\mathrm{N}$ ) ratio by $7 \%$ in the $0-10 \mathrm{~cm}$ soil depth. Nutrient budgets for P were balanced in all treatments, but $\mathrm{N}$ and $\mathrm{K}$ exports were higher under RT compared to CT. We conclude that RT is a suitable method for increasing indicators of soil fertility in organic farming systems. The combined effects of RT and an organic farming system with a diverse, ley-based crop rotation and organic fertilization merit further promotion and it may be considered for supporting actions by the agricultural policy schemes.
\end{abstract}

Key words: conservation tillage, soil fertility, organic fertilization, biodynamic preparations, nutrient budget, soluble soil nutrients

\section{Introduction}

Soil erosion and other forms of soil degradation are major problems facing agriculture today. Soils are not renewable over a human timescale. Most arable soils are prone to degradation, mainly caused by soil mismanagement. The degradation processes are more dependent on 'how' rather than on 'what' crops are grown', highlighting the importance of sustainable soil and crop management.

No-tillage (NT) and reduced tillage (RT) systems are well-known management tools for preventing soil erosion and conserving soil fertility ${ }^{2}$. A positive effect on soil organic carbon $\left(\mathrm{C}_{\text {org }}\right)$ contents in the superficial soil layer has frequently been reported ${ }^{2-7}$, whereas the effects on $\mathrm{C}_{\text {org }}$ in the whole profile are still a matter of controversy ${ }^{8}$. NT and RT cause a stratification of $\mathrm{C}_{\text {org }}$ and microbial properties in the soil profile ${ }^{3,6,9,10}$. The intensity of tillage operations in RT and the amount and management of above-ground crop residues affect the degree of stratification. Total N, organic N, mineralizable N, P and K usually follow the same pattern with a concentration in the surface layer and no change or decrease below ${ }^{10}$. 
Organic farming practices are reported to have a positive impact on air, soil, ground and surface water and biodiversity ${ }^{11}$. Multiple cropping systems, crop rotation, cover crops, organic fertilizers and minimum tillage can add organic matter to the soil and increase its capacity to circulate nutrients, air and water ${ }^{11}$. Crop production in organic farming relies and depends on nutrient transformation processes in the soil ${ }^{12}$. Soil quality is thus an important factor in organic farming and $\mathrm{C}_{\text {org }}$ is a lynchpin in this system. $\mathrm{C}_{\text {org }}$ in the topsoil is driven by interacting influences of climate, topography, soil type and aspects of crop management such as fertilization, tillage and crop rotation ${ }^{10}$. Conversion of natural land to crop production and tillage generally leads to a loss of $\mathrm{C}_{\text {org }}{ }^{13}$.

$\mathrm{C}_{\text {org }}$ was reported to remain constant in an organic farming system including ley-based crop rotations and application of organic fertilizers, while it decreased under conventional farming with mineral fertilization ${ }^{12}$. Munro et al. ${ }^{14}$ found organically managed topsoils to contain a higher percentage of organic matter, total $\mathrm{N}$ and available $\mathrm{P}$ when compared with their conventionally managed counterparts at 14 paired sites in England. Drinkwater et al. ${ }^{15}$ argue that the higher quality of added organic matter in organic farming leads to an accumulation of $\mathrm{C}_{\text {org }}$. Microbial communities are key regulators of soil organic matter dynamics and nutrient availability ${ }^{16}$. Soil microbial biomass and activity, both indicators of biological soil fertility, are enhanced by organic farming ${ }^{12,16}$. To ensure both shortterm productivity and long-term sustainability, achieving a balance between inputs and outputs of nutrients is critical, especially as the use of imported materials to build soil fertility is restricted under organic farming ${ }^{17}$. Suitable crop rotations containing legumes produce surpluses in the $\mathrm{N}$ budgets of organic farms. $\mathrm{P}$ and $\mathrm{K}$ budgets show both surpluses and deficits, depending on the farm type and the import of nutrients ${ }^{17,18}$.

The International Federation of Organic Agriculture Movements $^{19}$ recommends that organic farmers 'take measures to prevent erosion, compaction, salinisation and other forms of soil degradation'. Loss of topsoil should be minimized 'through minimal tillage, contour ploughing, crop selection, maintenance of soil plant cover and other management practices that conserve soil'.

Although conservation tillage (NT and RT) may improve the environmental and economic performance of organic farming, it is still not very common among organic farmers ${ }^{10}$. There are major concerns about the adoption of conservation tillage. Increased weed pressure under conservation tillage as a result of mechanical weed control techniques not adapted to high levels of crop residues on the surface would appear to be the main problem. Topsoil compaction, especially during the first years of transition and with limited availability of $\mathrm{N}$ mainly at the beginning of the growing season, also impedes conversion to conservation tillage. Well-drained clays, stable loams and calcareous soils combined with moderate precipitation are favorable conditions for conservation tillage under organic farming conditions. Suitable crop rotations with a high weed-suppressing capacity include a ley phase, cover crops and intercropping ${ }^{10}$.

The incorporation of the ley is a critical point under $\mathrm{RT}^{10,20}$. Only a few experiments have investigated RT under organic farming conditions. Severe weed competition $^{20-22}$ and technical difficulties while incorporating grass-clover sods ${ }^{20}$ led to the conclusion that an occasional use of the moldboard plough is inevitable to overcome weed pressure under RT in organic farming ${ }^{23}$. Schulz et al. ${ }^{24}$ consistently found similar yields in CT and RT, when at least shallow turning of the soil was carried out. The stratification of $\mathrm{C}_{\text {org }}$, soil nutrients and microbial properties with RT in organic or conventional farming systems all developed in a similar way. Under organic farming, RT changed the allocation of $\mathrm{C}_{\text {org }}$ within the topsoil but did not enhance $\mathrm{C}_{\text {org }}$ over the whole investigated soil profile ${ }^{24}$. Emmerling ${ }^{25}$ reported an increase in $\mathrm{C}_{\text {org }}$ in the $0-25 \mathrm{~cm}$ soil depth where $\mathrm{C}_{\text {org }}$ was enhanced in the upper layer $(0-15 \mathrm{~cm})$ and decreased in the layer below $(15-25 \mathrm{~cm})$. Microbial biomass and microbial activity in these soils were stratified under RT; there was an overall increase in microbial properties but the content of plant-available $\mathrm{P}$ in the investigated soil layer did not change ${ }^{25}$.

Conservation tillage (NT and RT) in organic farming has not yet been successfully adapted and further research into the adaptation of conservation tillage to different soils and climatic conditions, the development of suitable crop rotations and management practices to promote weed control and new strategies to remove and incorporate leys in a conservation tillage system are required ${ }^{10}$. The influence of different fertilization strategies in organic farming systems with and without livestock on N-mineralization and thus on reduced $\mathrm{N}$ supply under conservation tillage is not yet clearly understood.

In the present experiment the implementation of RT in an organic farming system with livestock was studied. Two fertilization strategies, the effects of biodynamic preparations and their interactions with soil tillage were investigated. Results of the conversion period from CT to RT showed an increase in $\mathrm{C}_{\text {org }}$, microbial biomass and microbial activity in the superficial soil layer over the first 3 years. In the first experimental period, average yields of cereals and sunflowers under RT were $93 \%$ of those obtained under $\mathrm{CT}^{26}$. After conversion, yields of fodder crops such as grass-clover and silage maize were $29 \%$ higher under RT, despite a considerably higher weed infestation of silage maize under $\mathrm{RT}^{27}$, directing the focus on soil fertility. This paper presents the effects of tillage, organic fertilization strategies and biodynamic preparations on soil fertility indicators such as $\mathrm{C}_{\text {org }}$, microbial biomass, microbial activity, soil nutrients and nutrient budgets after the first 6-year crop rotation period of a long-term experiment on a clayey soil in a temperate climate. 
Table 1. Dates of soil tillage in the different tillage systems.

\begin{tabular}{llll}
\hline System & Crop & Tillage & Date \\
\hline Conventional & Winter wheat & Plough & October 11, 2002 \\
& & October 30, 2002 & August 19, 2003 \\
& Intercrop-Oat-clover & Rotiller & February 26, 2004 \\
& Sunflower & Plough & April 22, 2004 \\
& & Rototiller & November 8, 2004 \\
& Spelt & Plough & November 16, 2004 \\
& & Rototiller & August 13, 2005 \\
& Grass-clover & Rototiller & February 25, 2008 \\
& Silage maize & Plough & May 9, 2008 \\
& & Rototiller & October 30, 2002 \\
Reduced & Winter wheat & Rototiller & August 6, 2003 \\
& & Chisel & August 19, 2003 \\
& Intercrop-oat clover & Rototiller & April 22, 2004 \\
& Sunflower & Rototiller & November 16, 2004 \\
& Spelt & Rototiller & August 13, 2005 \\
& Grass-clover & Rototiller & September 14, 2007 \\
& Catch crop-winter pea & Stubble cleaner & September 15, 2007 \\
& & Chisel & October 11, 2007 \\
& & Rototiller & May 9, 2008 \\
& Silage maize & Rototiller & May 9, 2008 \\
& & &
\end{tabular}

Table 2. Organic matter (OM) input (manure, slurry and green manure) in the first crop rotation period $(2003-2008)\left(\mathrm{t} \mathrm{OM} \mathrm{ha}^{-1}\right)$.

\begin{tabular}{|c|c|c|c|c|c|c|c|c|c|c|c|}
\hline & & & & \multirow{2}{*}{$\begin{array}{l}\text { Wheat } \\
2003\end{array}$} & \multirow{2}{*}{$\begin{array}{c}\text { Sunflower } \\
2004\end{array}$} & \multirow{2}{*}{$\begin{array}{l}\text { Spelt } \\
2005\end{array}$} & \multicolumn{2}{|c|}{ Grass-clover } & \multirow{2}{*}{$\begin{array}{c}\text { Silage maize } \\
2008\end{array}$} & \multirow[b]{2}{*}{ Total } & \multirow{2}{*}{$\begin{array}{c}\text { Average yearly } \\
\text { input }\end{array}$} \\
\hline & & & & & & & 2006 & 2007 & & & \\
\hline \multicolumn{12}{|c|}{ Treatment } \\
\hline I & Con & $\mathrm{MC}$ & $\mathrm{P}-$ & 2.82 & 1.08 & 2.15 & 2.36 & 1.30 & 0.76 & 10.47 & 1.75 \\
\hline II & Con & $\mathrm{MC}$ & $\mathrm{P}+$ & 2.68 & 1.25 & 2.05 & 2.30 & 1.26 & 0.76 & 10.31 & 1.72 \\
\hline III & Con & Slu & $\mathrm{P}-$ & 2.07 & 0.72 & 0.94 & 2.31 & 1.39 & 0.21 & 7.63 & 1.27 \\
\hline IV & Con & Slu & $\mathrm{P}+$ & 2.07 & 0.72 & 0.94 & 2.19 & 1.38 & 0.26 & 7.55 & 1.26 \\
\hline V & Red & $\mathrm{MC}$ & $\mathrm{P}-$ & 2.82 & 1.08 & 2.43 & 2.33 & 1.30 & 2.49 & 12.45 & 2.07 \\
\hline VI & Red & $\mathrm{MC}$ & $\mathrm{P}+$ & 2.68 & 1.25 & 2.33 & 2.28 & 1.26 & 2.49 & 12.29 & 2.05 \\
\hline VII & Red & Slu & $\mathrm{P}-$ & 2.07 & 0.72 & 1.22 & 2.38 & 1.39 & 1.94 & 9.71 & 1.62 \\
\hline VIII & Red & Slu & $\mathrm{P}+$ & 2.07 & 0.72 & 1.22 & 2.25 & 1.38 & 1.98 & 9.62 & 1.60 \\
\hline
\end{tabular}

Silage maize 2008, RT including pea green manure; OM, organic matter.

Con, CT; Red, RT; MC, manure compost; Slu, slurry; P-, without preparations; $\mathrm{P}+$, with preparations.

\section{Material and Methods}

\section{Field experiment}

In autumn 2002, a field experiment was conducted at Frick, Switzerland $\left(47^{\circ} 30^{\prime} \mathrm{N}, 8^{\circ} 01^{\prime} \mathrm{E}\right)$ involving factors such as tillage, fertilization and biodynamic preparations. A detailed description of the experiment is given by Berner et al. ${ }^{26}$.

CT uses a moldboard plough operating at $15 \mathrm{~cm}$ depth. A chisel plough $(15 \mathrm{~cm})$ was used in the RT system and grass-clover in the RT system was superficially incorporated with a stubble cleaner running at $5 \mathrm{~cm}$ depth. Seedbed preparation was performed by a rotary harrow in both tillage systems (Table 1).

Inputs of organic matter (Table 2) were higher in the manure compost than in the slurry system due to the use of straw for animal bedding. The experimental farm where the experiment is performed operates at a stocking density of 1.8 livestock units (LU) ha ${ }^{-1}$ consisting mainly of cattle. The farm has 19 ha of grassland and pastures and 13 ha of arable land. Mainly fodder crops are grown and additional fodder for swine breeding is purchased. Fertilization was planned at a stocking density of $1.4 \mathrm{LU} \mathrm{ha}^{-1}$. Differences in fertilization levels of $\mathrm{N}, \mathrm{P}$ and $\mathrm{K}$ were due to different proportions of excreted elements in solid and liquid organic manure types in the stable system and to $\mathrm{N}$ losses during manure storage. We aimed at achieving identical fertilization levels for $\mathrm{P}$ and thus accepted differences for $\mathrm{N}$ and $\mathrm{K}$. Consequently, plots with slurry fertilization received $\mathrm{N}, \mathrm{P}$ and $\mathrm{K}$ at levels of $1.13,1.41$ and $1.17 \mathrm{LU} \mathrm{ha}^{-1}$, respectively. Fertilization with the manure compost treatment was 
Table 3. $F$-values and significance levels of the mixed-model with repeated measures in 2002, 2005 and $2008 \mathrm{for}_{\mathrm{pH}} \mathrm{H}_{2} \mathrm{O}$ and soil organic carbon $\left(\mathrm{C}_{\mathrm{org}}\right)$.

\begin{tabular}{|c|c|c|c|c|}
\hline & \multicolumn{2}{|c|}{$\mathbf{p H}_{\mathrm{H}_{2} \mathrm{O}}$} & \multicolumn{2}{|c|}{$\mathrm{C}_{\text {org }}$} \\
\hline & $0-10 \mathrm{~cm}$ & $10-20 \mathrm{~cm}$ & $0-10 \mathrm{~cm}$ & $10-20 \mathrm{~cm}$ \\
\hline Tillage & $19.94 *$ & 0.69 & $84.01 * *$ & 5.35 \\
\hline Fertilization $*$ Preparations & 1.61 & 0.89 & 1.77 & 0.7 \\
\hline Tillage $*$ Fertilization $*$ Preparations & 1.18 & 0.58 & 0.52 & 1.76 \\
\hline Year & $32.54 * * *$ & $17.53 * *$ & $37.91 * * *$ & $4.67(*)$ \\
\hline Year*Tillage & $8.33^{*}$ & 0.22 & $22.82 * *$ & 0.47 \\
\hline Year $*$ Fertilization $*$ Preparations & $2.13(*)$ & 0.36 & 1.04 & 0.24 \\
\hline Year $*$ Tillage $*$ Fertilization $*$ Preparations & $2.35(*)$ & 1.85 & $2.24(*)$ & $2.21(*)$ \\
\hline
\end{tabular}

$(*) P<0.1 ; * P<0.05 ; * * P<0.01 ; * * * P<0.001$.

carried out at levels corresponding to 1.18, 1.53 and 1.09 $\mathrm{LU} \mathrm{ha}^{-1}$ for $\mathrm{N}, \mathrm{P}$ and $\mathrm{K}$, respectively (see Table 7 for average yearly inputs).

The biodynamic preparations $(\mathrm{P})$ consisted of the following: P 500, cow-manure fermented in a cow horn; $\mathrm{P} 501$, silica stored in a cow horn. These were applied at rates of 250 and $4 \mathrm{~g} \mathrm{ha}^{-1}$, respectively and sprayed three times per season on the relevant plots. Composting additives in the biodynamic treatment were yarrow flowers (P 502, Achillea millefolium L.), camomile flowers (P 503, Matricaria recutita, L.), stinging nettle (P 504, Urtica dioica, L.), oak bark (P 505, Quercus robur, L.), dandelion flowers (P 506, Taraxacum officinale, Wiggers) and valerian flowers (P 507, Valeriana officinalis, L.); these were added at the start of manure composting or slurry storage $^{28,29}$. In total, $10 \mathrm{~g}$ preparations were added to about $2 \mathrm{t}$ of composted raw material and $10 \mathrm{~g}$ preparations were also added to the slurry volume of $20 \mathrm{~m}^{3}$ with the biodynamic preparations.

The three factors-tillage, fertilization and preparations-were fully factorized. This resulted in eight treatments, each replicated four times. The 32 plots were arranged in a strip-plot design. The plot size was $12 \mathrm{~m} \times 12 \mathrm{~m}$, allowing the use of regular-sized farming equipment. Soil samples were taken and yields were measured in an inner $8 \mathrm{~m} \times 8 \mathrm{~m}$ parcel.

\section{Site conditions}

The soil type at the experimental site was a Stagnic Eutric Cambisol with $45 \%$ clay content [coefficient of variance (cv) $15 \%$ ] and a $\mathrm{pH}_{\mathrm{H}_{2} \mathrm{O}}$ of 7.1 (cv 4\%). It was enriched in ammonia acetate-EDTA extractable $\mathrm{P}$ and $\mathrm{K}$ due to extensive application of manure from livestock (swine) in pre-study conventional management.

Before the experiment started, the field was under conventional management and had been managed organically for 7 years in accordance with the European Union Regulation (EEC) No. 834/2007. The ploughing depth was $22 \mathrm{~cm}$ under conventional farming and $15 \mathrm{~cm}$ under organic farming prior to the start of the experiment. $\mathrm{C}_{\text {org }}$ in the ploughed soil depth was therefore distributed relatively homogeneously.

The mean annual precipitation at the site was $1000 \mathrm{~mm}$. In rainy periods the soil can be waterlogged for some days. The mean annual temperature was $8.9^{\circ} \mathrm{C}$.

\section{Crops}

A ley-based rotation was established from 2003 to 2008 (Table 1). Cereal and sunflower grains, cereal straw, the oat-clover intercrop, grass-clover and silage maize were removed from the field. In the RT system only a winter pea catch crop was established before silage maize and incorporated in spring.

Cereal yields were $11 \%$ lower under RT compared to CT, whereas sunflower yields were increased by $5 \%$ under $\mathrm{RT}^{26}$. Yields of grass-clover and silage maize were enhanced by 26 and $34 \%$, respectively in RT plots ${ }^{27}$.

\section{Soil sampling}

Soil samples were taken at the beginning of the experiment on October 1, 2002 (after harvest of silage maize), on March 15, 2005 (standing crop: spelt) and on September 25, 2008 (after harvest of silage maize) in all 32 experimental plots. Twelve individual cores (diameter $3 \mathrm{~cm}$ ) per field plot were separated into $0-10 \mathrm{~cm}$ and $10-20 \mathrm{~cm}$ soil depth layers and thereafter bulked to one composite sample per plot and layer. Soils were then sieved through a 5-mm mesh and kept at $3^{\circ} \mathrm{C}$ until they were analyzed.

\section{Chemical soil analysis}

Measurement of $\mathbf{p H}$ and $\mathbf{C}_{\mathrm{org}}$. The $\mathrm{pH}$ of dried samples $\left(60^{\circ} \mathrm{C}, 24 \mathrm{~h}\right)$ was measured in a soil suspension with deionized water $(1: 10, \mathrm{w} / \mathrm{v}) . \mathrm{C}_{\text {org }}$ was measured after wet oxidation of $1 \mathrm{~g}$ of dry soil in $20 \mathrm{ml}$ concentrated $\mathrm{H}_{2} \mathrm{SO}_{4}$ and $25 \mathrm{ml} 2 \mathrm{M} \mathrm{K}_{2} \mathrm{Cr}_{2} \mathrm{O}_{7}$ in accordance with Swiss standard protocols ${ }^{30}$.

Measurement of soil nutrient contents. Soluble nutrients $\mathrm{P}$ and $\mathrm{K}$ were extracted with $\mathrm{CO}_{2}$-saturated water $\left(\mathrm{P}_{\mathrm{CO}_{2}}, \mathrm{~K}_{\mathrm{CO}_{2}}\right)$ according to Swiss standard protocols ${ }^{30}$. 
The plant-available exchangeable fraction of $\mathrm{P}$ $\left(\mathrm{P}_{\text {Aac-EDTA }}\right)$ was extracted with ammonium acetateEDTA. Phosphate in the extract was measured after complex formation with added ammonium molybdate in a spectrophotometer at $750 \mathrm{~nm}$. Available $\mathrm{K}$ in the ammonium acetate-EDTA extract $\left(\mathrm{K}_{\mathrm{Aac}-\mathrm{EDTA}}\right)$ was measured by atom absorption spectrometry at $766.5 \mathrm{~nm}^{30}$.

\section{Soil microbial analyses}

All soil microbial analyses were carried out on moist soil samples adjusted to a water content corresponding to $40-50 \%$ of maximum water retention capacity.

Chloroform fumigation extraction (CFE). Soil microbial biomass $\mathrm{C}\left(\mathrm{C}_{\text {mic }}\right)$ and $\mathrm{N}\left(\mathrm{N}_{\text {mic }}\right)$ were estimated by CFE in accordance with Vance et al. ${ }^{31}$. CFE was done in triplicate on $20 \mathrm{~g}$ (dry matter) subsamples that were extracted with $80 \mathrm{ml}$ of a $0.5 \mathrm{M} \mathrm{K}_{2} \mathrm{SO}_{4}$ solution. Total organic $\mathrm{C}$ (TOC) in soil extracts was determined by infrared spectrometry after combustion at $850^{\circ} \mathrm{C}$ (DIMA-TOC 100, Dimatec, 45276 Essen, Germany). Total N was subsequently measured in the same sample by chemoluminescence (TNb, Dimatec, 45276 Essen, Germany). Soil microbial biomass was then calculated according to the formula: $\mathrm{C}_{\mathrm{mic}}=\mathrm{EC} / k_{\mathrm{EC}}$, where $\mathrm{EC}=(\mathrm{TOC}$ in fumigated samples-TOC in control samples) and $k_{\mathrm{EC}}=0.45^{32}$. $\mathrm{N}_{\text {mic }}=\mathrm{EN} / k_{\mathrm{EN}}$, where $\mathrm{EN}=$ (total $\mathrm{N}$ extracted from fumigated samples-total $\mathrm{N}$ extracted from control samples) and $k_{\mathrm{EN}}=0.54^{33}$.

Soil DHA. DHA was measured according to Tabatabai $^{34}$ in $5 \mathrm{~g}$ of soil samples incubated at $30^{\circ} \mathrm{C}$ for $24 \mathrm{~h}$ in the presence of an alternative electron acceptor [triphenyltetrazolium chloride (TTC)]. The red-colored product [triphenylformazan (TPF)] was extracted with acetone and measured in a spectrophotometer at $546 \mathrm{~nm}$.

\section{Nutrient balances}

Nutrient balances for N, P and K were calculated on a field basis. Wheat grains and straw, oat-clover intercrop, sunflower seeds, spelt grains and straw, grass-clover, winter pea and silage maize samples were analyzed for nutrient concentrations. Nitrogen was determined after Kjeldahl digestion. For measuring $\mathrm{P}$ and $\mathrm{K}$, samples were incinerated at $600^{\circ} \mathrm{C}$ and the ash extracted with concentrated hydrochloric acid. $\mathrm{N}$ and $\mathrm{P}$ concentrations were determined photometrically and $\mathrm{K}$ via atom absorption spectrometry. Nutrients (N, P and K) in slurry and manure compost were extracted with hydrochloric acid after the samples had been incinerated at $600^{\circ} \mathrm{C}$ and were analyzed as specified above. Biological $\mathrm{N}$-fixation by legumes, atmospheric deposition, leaching and gaseous emissions of nutrients were not considered in the balances. The winter pea catch crop contained $62 \mathrm{~kg} \mathrm{~N}^{-1}$ and was exclusively incorporated into the soil of the RT system. Although it was assumed that the whole quantity of catch crop $\mathrm{N}$ was not fixed biologically, it was included in the nitrogen budget.

\section{Statistics}

The statistical model used involved tillage as the main factor in the strip-plot design and Fertilization $*$ Preparations as a combined factor. Soil microbial properties and nutrient contents were calculated with a general linear model to test for significance using SPSS 15.0 software (SPSS Inc., Chicago, Illinois, USA, 2006). Linear contrasts were then calculated for fertilization and preparations using SAS 9.1 software (SAS Institute Inc., Cary, North Carolina, USA, 2002-2003). A mixed model in SAS was used to perform a time line analysis for $\mathrm{pH}$ and $\mathrm{C}_{\text {org }}$ with the fixed factors Tillage, Fertilization*Preparations and Year (Year as a repeated measure). The Block was used as a random factor. In the result tables, first the means of the eight basic treatments were presented. Second the relative differences between the factors tillage, fertilization and preparation were shown. Third, the significant differences between the three factors and respective interactions were depicted. The levels of probability $P<0.05, P<0.01$ and $P<0.001$ were declared significantly different.

\section{Results and Discussion}

After the first 6-year crop rotation period of the present experiment, statistical analysis revealed no effects of fertilization and only slight effects of preparations on the investigated properties while the response to tillage was strong, especially in the $0-10 \mathrm{~cm}$ soil depth layer. A distinct stratification of $\mathrm{C}_{\text {org }}$, microbial biomass $\mathrm{C}$ and $\mathrm{N}$, microbial activity, plant-available $\mathrm{P}$ and $\mathrm{K}$ was found under RT, while they were distributed relatively homogeneously throughout 0-20 cm under CT.

\section{pH and $C_{\text {org }}$}

A mixed model analysis of variance (ANOVA) with repeated measures in 2002, 2005 and 2008 was used to identify significant changes of $\mathrm{pH}$ and $\mathrm{C}_{\text {org }}$ over the first crop rotation period. The factors Year in both soil layers and Tillage in the $0-10 \mathrm{~cm}$ soil layer showed significant effects. There was no effect of the combined factor Fertilizer*Preparations. The interaction Year*Tillage significantly affected $\mathrm{pH}$ and $\mathrm{C}_{\text {org }}$ in the $0-10 \mathrm{~cm}$ soil layer (Table 3 ).

Soil pH deceased significantly from 2002 to 2005 under both tillage treatments and in both soil depths. When compared with the initial values of 2002, $\mathrm{pH}$ values in 2008 were significantly lower only under RT (Table 4, Fig. 1). The decrease of $\mathrm{pH}$ was highest under $\mathrm{RT}$ in $0-10 \mathrm{~cm}$ $(-0.17, P<0.01)$.

According to Rasmussen ${ }^{5}$, soil acidity under RT increases in the long run by $0.2-0.3$ units in topsoil, which may be due to an accumulation of organic acids in the superficial layer ${ }^{35}$. These findings are in agreement with the results of the present experiment. On the other hand, CT may prevent ions from leaching by turning the soil and thus retard acidification of the topsoil ${ }^{36}$. Seasonal differences 
causing the lower levels measured in spring 2005 cannot be excluded.

Under RT $\mathrm{C}_{\text {org }}$ in the $0-10 \mathrm{~cm}$ soil layer in 2008 was $19 \%$ higher $(P<0.001)$ than the initial values in 2002 . This represents an increase from $2.19 \% \mathrm{C}_{\text {org }}$ to $2.61 \% \mathrm{C}_{\text {org }}$ within 6 years. $\mathrm{C}_{\text {org }}$ remained constant under CT (Fig. 1). No significant differences were found in the $10-20 \mathrm{~cm}$ soil layer and there were no effects of fertilization or preparations.

$\mathrm{C}_{\text {org }}$ is considered an important indicator of soil fertility. The increase in $C_{\text {org }}$ in our experiment in the $0-10 \mathrm{~cm}$ soil layer under RT measured in $2005^{26}$ continued between 2005 and 2008. In a meta-study, Ogle et al. ${ }^{37}$ found $\mathrm{C}_{\mathrm{org}}$ increased by $16 \%$ in $0-30 \mathrm{~cm}$ depth after 20 years of NT in a temperate wet climate. Alvarez ${ }^{4}$ found no differences in $\mathrm{C}_{\text {org }}$ accumulation between NT and RT. In this meta-study, the amount of $\mathrm{C}_{\text {org }}$ integrated over $30 \mathrm{~cm}$ soil depth under NT and RT was $14 \%$ higher than under CT, if only longterm experiments were taken into account. The increase in $\mathrm{C}_{\text {org }}$ took place only in the $0-15 \mathrm{~cm}$ soil layer, and no differences were reported below $15 \mathrm{~cm}$, which corresponds to our findings. Our results are in line with those of Pekrun and Claupein ${ }^{2}$, Rasmussen ${ }^{5}$, Kladivko ${ }^{6}$ and Koch and Stockfisch ${ }^{7}$. Under organic farming conditions, Emmerling $^{25}$ reported a relative increase in $\mathrm{C}_{\text {org }}$ of $7-10 \%$ in the surface layer after 10 years of RT, with no differences below the tilled layer. Other studies found an increase in $\mathrm{C}_{\text {org }}$ in the superficial layer but a decrease in the untilled soil layers below ${ }^{3,39,40}$. Insufficient plant material left on the field may be a reason for the failure of RT to enhance $\mathrm{C}_{\text {org }}$. By contrast, input of organic matter via crop rotation and organic fertilizers in the present experiment were high compared to other RT trials (Table 2). This seems to be important, as Baker et al. ${ }^{8}$ argue that $\mathrm{C}_{\text {org }}$ gains in most cases are based only on near-surface samples $(0-30 \mathrm{~cm})$. Changes in $\mathrm{C}_{\text {org }}$ disappear when deeper sampling (below $30 \mathrm{~cm}$ ) is included. Under organic farming conditions, Schulz et al. ${ }^{24}$ found no increase in $\mathrm{C}_{\text {org }}$ after 12 years of RT but $\mathrm{C}_{\text {org }}$ was altered by inducing a ley phase into the crop rotation and with amendment of manure. Many authors ${ }^{2,41,42}$ argue that periodical use of moldboard ploughing may be inevitable in organic farming to control weed problems. However, high losses of $\mathrm{C}_{\text {org }}$ have been reported after single-moldboard ploughing in an RT system, proportional to the previous gain under NT or RT in some studies ${ }^{7,43,44}$. In other studies, no changes could be observed in $\mathrm{C}_{\text {org }}$ after ploughing of $\mathrm{NT}$ soils ${ }^{45-47}$. If periodical intervention is only cultivating or ripping and not ploughing, then most of the previously gained $\mathrm{C}_{\mathrm{org}}$ could be prevented from mineralization ${ }^{43}$. Organic fertilizers, especially manure, enhance more stable fractions of $\mathrm{C}_{\text {org }}{ }^{48,49}$ and thus $\mathrm{C}_{\text {org }}$ accumulated under $\mathrm{RT}$ in stocked organic farming systems may be more resistant to decomposition after moldboard ploughing than in stockless systems. Peigné et al. ${ }^{10}$ think that the combined effect of organic farming and RT could also improve the soil organic matter content and consequently soil nutrient reserves in 

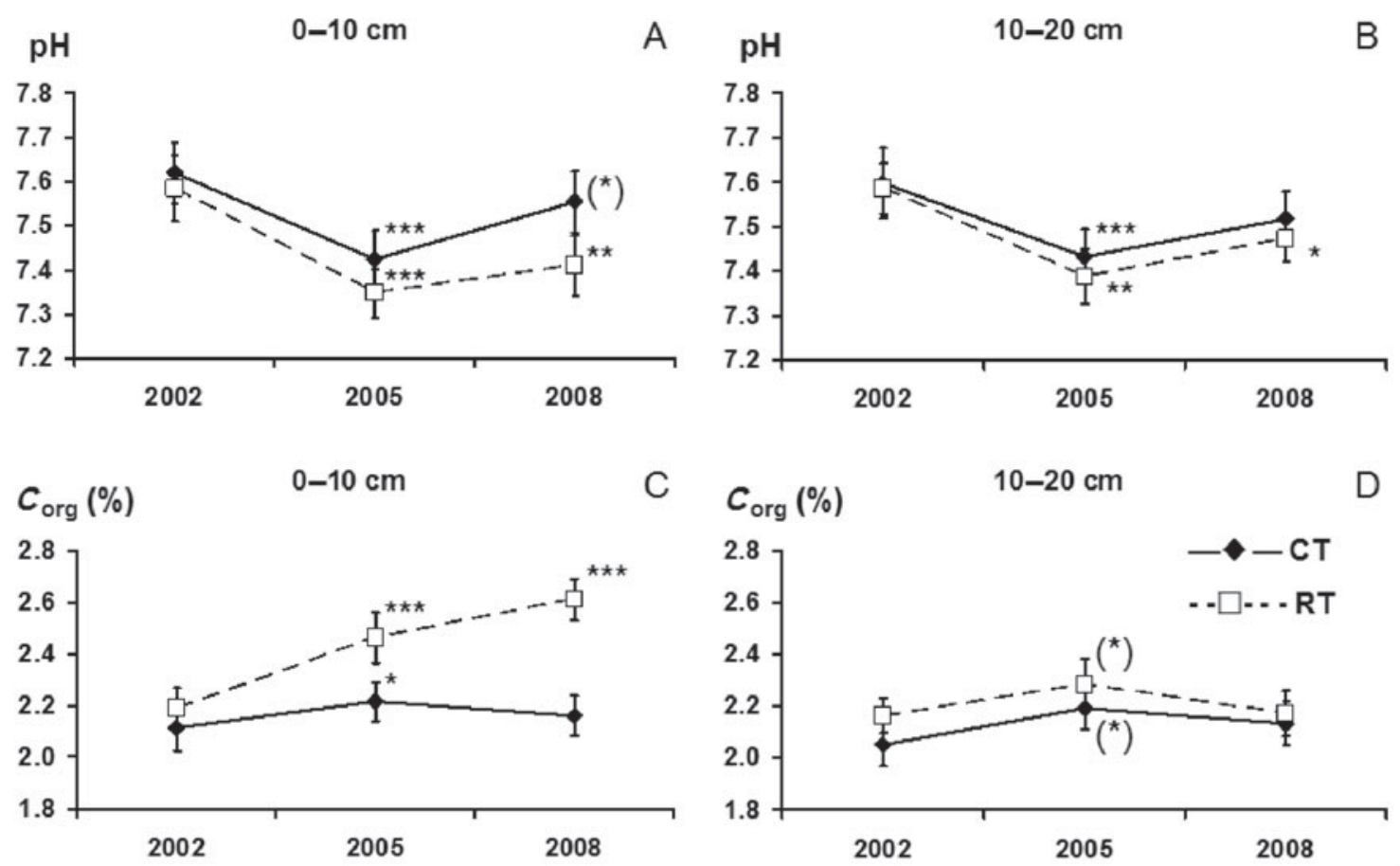

Figure 1. Means and standard error of the mean of $\mathrm{pH}_{\mathrm{H}_{2} \mathrm{O}}$ and soil organic carbon $\left(\mathrm{C}_{\mathrm{org}}\right)$ in $0-10 \mathrm{~cm}$ and $10-20 \mathrm{~cm}$ soil depth for RT and CT in the years 2002, 2005 and 2008. A, B: pH. C, D: soil organic carbon [ $\left.\mathrm{C}_{\text {org }}(\%)\right]$. Results of the mixed model $t$-test for the factor Year*Tillage, stars indicate significant differences of the means of each treatment in 2005 and 2008 compared with the corresponding mean in 2002. (*) $P<0.1, * P<0.05, * * P<0.01$, *** $P<0.001$.

stockless organic systems and call for further research on this issue.

\section{Soil microbial biomass and activity}

Soil microbial biomass $\left(\mathrm{C}_{\text {mic }}, \mathrm{N}_{\text {mic }}\right)$ and microbial activity (DHA) were highly stratified under RT, whereas they were relatively homogeneously distributed throughout the profile under CT. Soil microbial biomass was greater under RT in the $0-10 \mathrm{~cm}$ soil layer, $\mathrm{C}_{\text {mic }}$ being $37 \%(P<0.01)$ and $\mathrm{N}_{\text {mic }}$ $35 \%(P<0.05)$ greater than under CT (Table 5). Under RT, $\mathrm{C}_{\text {mic }}$ was also greater by $10 \%(P<0.05)$ than under $\mathrm{CT}$ in the $10-20 \mathrm{~cm}$ soil layer, whereas $\mathrm{N}_{\text {mic }}$ showed no significant difference between the two tillage treatments.

Despite $8 \%$ higher average values in the $10-20 \mathrm{~cm}$ layer, tillage effects on the $\mathrm{C}_{\text {mic }}$-to- $\mathrm{N}_{\text {mic }}$ ratio were not significant. However, a $7 \%$ greater $\mathrm{C}_{\text {mic }}$-to- $\mathrm{N}_{\text {mic }}$ ratio $(P<0.05)$ was found with the use of biodynamic preparations.

The $\mathrm{C}_{\text {mic }}$-to- $\mathrm{C}_{\text {org }}$ ratio, which is considered to be an indicator of biological soil fertility ${ }^{38,50}$, was $14 \%$ greater $(P<0.05)$ under RT than under $\mathrm{CT}$ in the $0-10 \mathrm{~cm}$ soil layer. Microbial activity (DHA) was greater by $57 \%$ $(P<0.05)$ under RT compared to $\mathrm{CT}$ in the $0-10 \mathrm{~cm}$ soil depth. In the $10-20 \mathrm{~cm}$ layer, DHA was greater under RT by $17 \%$ as compared to $\mathrm{CT}(P<0.05)$.

Microbial biomass and activity are considered to be early indicators of changes in soil properties induced by tillage regimes $^{9}$. A strong differentiation of the microbial biomass between tilled and untilled layers under RT was found in the present experiment; this corresponds with the results obtained by other authors ${ }^{9,25,51,52}$. While we also found greater microbial biomass $C$ in the $10-20 \mathrm{~cm}$ soil layer, others reported no difference ${ }^{9}$ in ATP contents ${ }^{36}$ or less microbial biomass ${ }^{25,38}$ in the untilled layer. Microbial biomass is strongly affected by freshly added organic matter $^{52}$. Friedel et al. ${ }^{36}$ accordingly found a high dependence of microbial biomass distribution in the soil on the amount of fresh, decomposable organic matter in a tillage experiment. A clear stratification of the microbial biomass depending on the amount of plant residues in different intense silage maize rotation was found by Franzluebbers and Brock $^{53}$. The high input of organic matter in the Frick trial (Table 2) combined with the reduction of tillage may be the reason for the high levels of microbial biomass $\mathrm{C}$ and $\mathrm{N}$, even in the untilled $10-20 \mathrm{~cm}$ soil layer. The application of manure in the present experiment-in contrast to the stockless experiment described by Emmerling 25 , which was also conducted under organic farming conditions with a ley-based crop rotation-may have been a crucial factor in the dynamics of the microbial populations. Heinze et al. ${ }^{54}$ found enhanced microbial biomass as a result of application of manure.

Diversified crop rotations, reduction of tillage and adoption of organic farming are reported to result in a more fungal-dominated microbial community ${ }^{16}$. A higher $\mathrm{C}_{\text {mic }}$-to- $\mathrm{N}_{\text {mic }}$ ratio in the undisturbed $10-20 \mathrm{~cm}$ soil depth layer under RT in our experiment supports these findings as it indicates a higher proportion of fungi and older cells in 


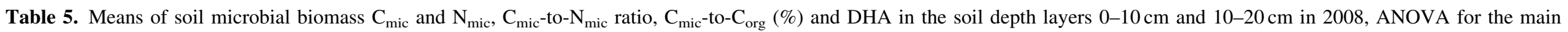
effects Tillage and Fertilization $*$ Preparations, linear contrasts for fertilization and preparations.

\begin{tabular}{|c|c|c|c|c|c|c|c|c|c|c|c|c|c|}
\hline & & & & \multicolumn{2}{|c|}{$\mathrm{C}_{\text {mic }}\left(\mathrm{mg} \mathrm{C}_{\mathrm{mic}} \mathrm{kg}^{-1}\right)$} & \multicolumn{2}{|c|}{$\mathbf{N}_{\text {mic }}\left(\mathbf{m g ~} \mathbf{N}_{\text {mic }} \mathrm{kg}^{-1}\right)$} & \multicolumn{2}{|c|}{$\mathrm{C}_{\text {mic }}-$-to- $\mathrm{N}_{\text {mic }}$ ratio } & \multicolumn{2}{|c|}{$\mathrm{C}_{\text {mic }}$-to- $\mathrm{C}_{\text {org }}(\%)$} & \multicolumn{2}{|c|}{ DHA $\left(\mu \mathrm{g}\right.$ TPF $\left.\mathrm{g}^{-1} \mathbf{d}^{-1}\right)$} \\
\hline & & & & $0-10 \mathrm{~cm}$ & $10-20 \mathrm{~cm}$ & $0-10 \mathrm{~cm}$ & $10-20 \mathrm{~cm}$ & 0-10 cm & $10-20 \mathrm{~cm}$ & $0-10 \mathrm{~cm}$ & $10-20 \mathrm{~cm}$ & $0-10 \mathrm{~cm}$ & $10-20 \mathrm{~cm}$ \\
\hline \multicolumn{14}{|c|}{ Treatment } \\
\hline I & Con & $\mathrm{MC}$ & $\mathrm{P}-$ & 891 & 830 & 132 & 126 & 6.82 & 6.61 & 3.79 & 3.92 & 395 & 350 \\
\hline II & Con & $\mathrm{MC}$ & $\mathrm{P}+$ & 782 & 806 & 113 & 125 & 7.03 & 6.44 & 3.45 & 3.80 & 331 & 346 \\
\hline III & Con & Slu & $\mathrm{P}_{-}$ & 773 & 774 & 118 & 123 & 6.60 & 6.31 & 3.72 & 3.75 & 323 & 337 \\
\hline IV & Con & Slu & $\mathrm{P}+$ & 758 & 784 & 108 & 122 & 7.12 & 6.50 & 3.71 & 3.72 & 304 & 320 \\
\hline V & Red & $\mathrm{MC}$ & $\mathrm{P}-$ & 1090 & 881 & 161 & 129 & 6.80 & 6.86 & 4.11 & 3.90 & 532 & 384 \\
\hline VI & Red & $\mathrm{MC}$ & $\mathrm{P}+$ & 1038 & 841 & 146 & 123 & 7.27 & 6.90 & 4.03 & 3.93 & 459 & 361 \\
\hline VII & Red & Slu & $\mathrm{P}-$ & 1023 & 876 & 152 & 128 & 6.75 & 6.88 & 3.93 & 4.17 & 499 & 404 \\
\hline VIII & Red & Slu & $\mathrm{P}+$ & 1046 & 878 & 153 & 127 & 6.94 & 6.98 & 4.23 & 4.21 & 489 & 380 \\
\hline Meal & & & & 925 & 834 & 135 & 125 & 6.92 & 6.68 & 3.87 & 3.92 & 417 & 360 \\
\hline \multicolumn{14}{|c|}{ Factor } \\
\hline \multicolumn{14}{|c|}{ Tillage } \\
\hline & (\%) (1 & conve & & 137 & 110 & 135 & 101 & 102 & 108 & 114 & 107 & 157 & 117 \\
\hline \multicolumn{14}{|c|}{ Fertilization } \\
\hline & ompos & $100 \%$ & & 101 & 101 & 101 & 101 & 101 & 99 & 97 & 98 & 101 & 97 \\
\hline \multicolumn{14}{|c|}{ Preparations } \\
\hline \multicolumn{4}{|c|}{ With (\%) $(100 \%=$ without $)$} & 98 & 99 & 94 & 98 & 107 & 102 & 100 & 99 & 94 & 98 \\
\hline \multicolumn{4}{|c|}{ ANOVA } & & \# & & & & & & & & \\
\hline \multicolumn{4}{|c|}{ Tillage } & $* *$ & * & $*$ & n.s. & n.s. & $(*)$ & $*$ & $(*)$ & * & $*$ \\
\hline \multicolumn{4}{|c|}{ Preparations } & n.s. & n.s. & $(*)$ & n.s. & $*$ & n.s. & n.s. & n.s. & n.s. & n.s. \\
\hline
\end{tabular}

$\mathrm{C}_{\text {mic }}$, soil microbial carbon; $\mathrm{N}_{\text {mic }}$, soil microbial nitrogen; $\mathrm{C}_{\mathrm{org}}$, soil organic carbon; DHA, dehydrogenase activity; TPF, triphenylformazan.

Con, conventional tillage; Red, RT; MC, manure compost; Slu, slurry; $\mathrm{P}-$, without preparations; $\mathrm{P}+$, with preparations.

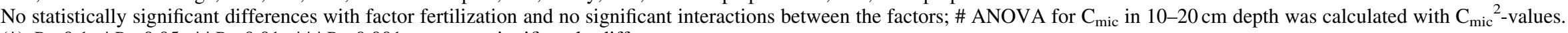
(*) $P<0.1 ; * P<0.05 ; * * P<0.01 ; * * * P<0.001 ;$ n.s., not significantly different. 
Table 6. Means of nutrient contents in the soil depth layers $0-10 \mathrm{~cm}$ and $10-20 \mathrm{~cm}$ in 2008, ANOVA for the main factors tillage and Fertilization $*$ Preparations, linear contrasts for fertilization and preparations.

\begin{tabular}{|c|c|c|c|c|c|c|c|c|c|c|c|}
\hline & & & & \multicolumn{2}{|c|}{$\mathrm{P}_{\mathrm{CO}_{2}}\left(\mathrm{mg} \mathrm{kg}^{-1}\right)$} & \multicolumn{2}{|c|}{$P_{\text {Aac-EDTA }}\left(\mathrm{mg} \mathrm{kg}^{-1}\right)$} & \multicolumn{2}{|c|}{$\mathrm{K}_{\mathrm{CO}_{2}}\left(\mathrm{mg} \mathrm{kg}^{-1}\right)$} & \multicolumn{2}{|c|}{$\mathrm{K}_{\text {Aac-EDTA }}\left(\mathrm{mg} \mathrm{kg}^{-1}\right)$} \\
\hline & & & & $0-10 \mathrm{~cm}$ & $10-20 \mathrm{~cm}$ & $0-10 \mathrm{~cm}$ & $10-20 \mathrm{~cm}$ & $0-10 \mathrm{~cm}$ & $0-20 \mathrm{~cm}$ & $0-10 \mathrm{~cm}$ & $10-20 \mathrm{~cm}$ \\
\hline \multicolumn{12}{|c|}{ Treatment } \\
\hline I & Con & $\mathrm{MC}$ & $\mathrm{P}-$ & 1.93 & 1.32 & 112 & 110 & 33.6 & 27.7 & 479 & 448 \\
\hline II & Con & $\mathrm{MC}$ & $\mathrm{P}+$ & 1.80 & 1.14 & 102 & 98 & 31.1 & 24.3 & 457 & 447 \\
\hline III & Con & Slu & $\mathrm{P}-$ & 1.95 & 1.20 & 111 & 105 & 30.8 & 27.4 & 433 & 419 \\
\hline IV & Con & Slu & $\mathrm{P}+$ & 1.62 & 1.53 & 106 & 122 & 31.7 & 27.4 & 447 & 439 \\
\hline $\mathrm{V}$ & Red & $\mathrm{MC}$ & $\mathrm{P}-$ & 3.60 & 1.46 & 145 & 114 & 44.6 & 24.4 & 564 & 429 \\
\hline VI & Red & $\mathrm{MC}$ & $\mathrm{P}+$ & 3.04 & 1.26 & 139 & 110 & 43.3 & 25.5 & 550 & 436 \\
\hline VII & Red & Slu & $\mathrm{P}-$ & 2.81 & 1.26 & 132 & 103 & 39.9 & 24.8 & 546 & 420 \\
\hline VIII & Red & Slu & $\mathrm{P}+$ & 3.09 & 1.56 & 131 & 119 & 50.9 & 26.5 & 575 & 422 \\
\hline Mean & & & & 2.48 & 1.34 & 122 & 110 & 38.2 & 26.0 & 506 & 433 \\
\hline \multicolumn{12}{|c|}{ Factor } \\
\hline \multicolumn{12}{|c|}{ Tillage } \\
\hline $\operatorname{Rec}$ & d $(\%)$ & $\%=\mathrm{co}$ & entional) & 172 & 107 & 127 & 103 & 140 & 95 & 123 & 97 \\
\hline \multicolumn{12}{|c|}{ Fertilization } \\
\hline Ma & $\mathrm{Com}$ & $(\%)(1$ & $b=$ slurry $)$ & 109 & 93 & 104 & 96 & 100 & 96 & 102 & 104 \\
\hline \multicolumn{12}{|c|}{ Preparations } \\
\hline Wi & 7) $(10$ & $=$ witho & & 93 & 105 & 95 & 104 & 105 & 99 & 100 & 102 \\
\hline \multicolumn{12}{|c|}{ ANOVA } \\
\hline Tillag & & & & $*$ & n.s. & $*$ & n.s. & $(*)$ & n.s. & $*$ & n.s. \\
\hline Fertili & Prepar & & & n.s. & n.s. & n.s. & n.s. & $(*)$ & n.s. & n.s. & n.s. \\
\hline
\end{tabular}

$\mathrm{P}_{\mathrm{CO}_{2}}, \mathrm{CO}_{2}$-extractable phosphorus; $\mathrm{K}_{\mathrm{CO}_{2}}, \mathrm{CO}_{2}$-extractable potassium.

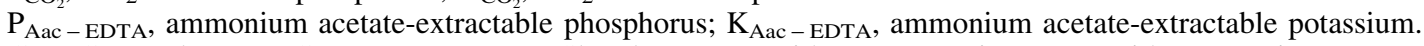

Con, CT; Red, RT; MC, manure compost; Slu, slurry; P-, without preparations; $\mathrm{P}+$, with preparations.

No statistically significant differences with factors fertilizer and preparations.

(*) $P<0.1 ; * P<0.05 ; * * P<0.01 ; * * * P<0.001$; n.s., not significantly different.

the total microbial biomass, whereas younger cells and a bacteria-dominated microflora would be reflected in a decrease in the $\mathrm{C}_{\text {mic }}$-to- $\mathrm{N}_{\text {mic }}$ ratio ${ }^{55}$. Guggenberger et al. ${ }^{56}$ and Emmerling ${ }^{25}$ found an increase in fungi in the upper soil layer under NT and RT. This, however, was not indicated by changes in the $\mathrm{C}_{\text {mic }}$-to- $\mathrm{N}_{\text {mic }}$ ratio in $0-10 \mathrm{~cm}$ soil depth in our experiment. The regular use of the roto tiller may have prevented the development of fungal biomass in the tilled layer in our experiment. Additionally, in the experiment described by Emmerling ${ }^{25}$, the green fallow and cereal straw were mulched and remained on the field, leaving high amounts of lignin and cellulose as a favorable substrate for the fungal population.

The $\mathrm{C}_{\text {mic }}{ }^{\text {-to- }} \mathrm{N}_{\text {mic }}$ ratio increased in the present experiment with the use of biodynamic preparations in $0-10 \mathrm{~cm}$. In contrast, Fließbach et al. ${ }^{12}$ found a lower $\mathrm{C}_{\text {mic }}$-to- $\mathrm{N}_{\text {mic }}$ ratio for a treatment with compost and biodynamic preparations compared to a manured conventional system. However, they were unable to say whether this effect was caused by composting or by the biodynamic preparations. Minor effects of biodynamic preparations on soil biology properties were found by Carpenter-Boggs et al. ${ }^{29}$, when compared with compost without preparations.

The $\mathrm{C}_{\text {mic }}$-to- $\mathrm{C}_{\text {org }}$ ratio in $0-10 \mathrm{~cm}$ under $\mathrm{RT}$ was $14 \%$ greater than that under CT. This difference was already apparent after 3 years of our trial ${ }^{26}$ and became smaller than the differentiation by $\mathrm{C}_{\text {org }}$. This confirmed the results obtained by Stockfisch et al. ${ }^{38}$, who consider the $\mathrm{C}_{\text {mic }}$-to$\mathrm{C}_{\text {org }}$ ratio to be an early indicator of an enhancement of $\mathrm{C}_{\text {org. }}$. Angers et al. ${ }^{40}$ found a $\mathrm{C}_{\text {mic }}$-to- $\mathrm{C}_{\text {org }}$ ratio three times greater under RT compared to $\mathrm{CT}$ in $0-16 \mathrm{~cm}$ after 11 years of silage maize rotation and low input of organic matter. An increase in the $\mathrm{C}_{\text {mic }}$-to- $\mathrm{C}_{\mathrm{org}}$ ratio of $16 \%$ in the superficial layer was also reported by Emmerling ${ }^{25}$.

We measured significantly greater microbial activity (DHA) under RT in both soil layers. Emmerling ${ }^{25}$ found soil respiration and alkaline phosphomonoesterase significantly higher in $0-15 \mathrm{~cm}$ under RT but no difference in the soil layer below. Similar results were obtained by von Lützow et al. ${ }^{52}$ and Kandeler et al. ${ }^{9}$. Von Lützow et al. ${ }^{52}$ reported higher microbial biomass and activity in clay soils because the conditions for micro-organisms were more stable, although $\mathrm{C}_{\text {org }}$ was less accessible to the microbial community.

\section{Phosphorus and potassium}

As with $\mathrm{C}_{\text {org }}$, microbial biomass and microbial activity, a clear stratification, especially of soluble $\mathrm{P}_{\mathrm{CO}_{2}}$ and $\mathrm{K}_{\mathrm{CO}}$, was found after 6 years under RT. $\mathrm{P}_{\mathrm{CO}_{2}}$ in the $0-10 \mathrm{~cm}$ soil layer in 2008 was greater by $72 \%(P<0.05)$ in RT than in CT plots, while the exchangeable $\mathrm{P}_{\mathrm{Aac}-\mathrm{EDTA}}$ was only greater by $27 \%(P<0.05)$ (Table 6$). \mathrm{K}_{\mathrm{CO}_{2}}$ was greater by $40 \%$ $(P<0.1)$ in RT than in CT in the $0-10 \mathrm{~cm}$ layer in 2008 
Table 7. Nutrient budgets on a field basis for nitrogen $(\mathrm{N})$, phosphorus $(\mathrm{P})$ and potassium $(\mathrm{K})$ for the first crop rotation period (2003-2008).

\begin{tabular}{|c|c|c|c|c|c|c|c|c|c|c|c|c|}
\hline & & & & \multicolumn{3}{|c|}{$N\left(\mathrm{~kg} \mathrm{ha}^{-1} \mathrm{yr}^{-1}\right) \#$} & \multicolumn{3}{|c|}{$P\left(\mathrm{kgha}^{-1} \mathrm{yr}^{-1}\right)$} & \multicolumn{3}{|c|}{$\mathrm{K}\left(\mathrm{kg} \mathrm{ha}^{-1} \mathrm{yr}^{-1}\right)$} \\
\hline & & & & Input & Yield & Surplus & Input & Yield & Surplus & Input & Yield & Surplus \\
\hline \multicolumn{13}{|c|}{ Treatment } \\
\hline I & Con & $\mathrm{MC}$ & $\mathrm{P}-$ & 109 & 113 & -4 & 29 & 23 & 7 & 153 & 101 & 52 \\
\hline II & Con & $\mathrm{MC}$ & $\mathrm{P}+$ & 105 & 122 & -17 & 30 & 23 & 7 & 150 & 103 & 48 \\
\hline III & Con & Slu & $\mathrm{P}-$ & 109 & 135 & -25 & 24 & 27 & -3 & 164 & 125 & 39 \\
\hline IV & Con & Slu & $\mathrm{P}+$ & 107 & 131 & 24 & 24 & 25 & -1 & 164 & 116 & 48 \\
\hline V & Red & $\mathrm{MC}$ & $\mathrm{P}-$ & 112 & 158 & -47 & 30 & 27 & 3 & 159 & 139 & 19 \\
\hline VI & Red & $\mathrm{MC}$ & $\mathrm{P}+$ & 108 & 157 & -50 & 30 & 26 & 3 & 156 & 138 & 18 \\
\hline VII & Red & Slu & $\mathrm{P}_{-}$ & 114 & 161 & -47 & 25 & 28 & -3 & 172 & 140 & 32 \\
\hline VIII & Red & Slu & $\mathrm{P}+$ & 111 & 154 & -43 & 25 & 27 & -2 & 171 & 142 & 29 \\
\hline Mean & & & & 109 & 141 & -32 & 27 & 26 & 1 & 161 & 126 & 36 \\
\hline
\end{tabular}

Values presented are annual means. \# Biological nitrogen fixation not considered.

Con, CT; Red, RT; MC, manure compost; Slu, slurry; P-, without preparations; P+, with preparations.

and $\mathrm{K}_{\text {Aac - EDTA }}$ was greater by $+23 \%(P<0.05)$. There were no significant tillage effects in the $10-20 \mathrm{~cm}$ soil layer and no effects of fertilization or preparations in both layers.

The small differences between the nutrient budgets for $\mathrm{P}$ and $\mathrm{K}$ in CT and RT cannot be the reason for the high differences in nutrient contents between the two tillage systems. The surplus of $\mathrm{K}$ was even greater under CT (Table 7). Yields of forage crops (grass-clover and silage maize) were greater under RT; larger quantities of crop residues and root biomass were also left on the field. Rasmussen $^{5}$ reported a significant increase in plantavailable $\mathrm{P}$ in $0-5 \mathrm{~cm}$ soil depth under RT in various studies, while available $P$ in $10-20 \mathrm{~cm}$ remained stable or even decreased. A stratification of plant-available $\mathrm{P}$ similar to $\mathrm{C}_{\text {org }}$ was also found by Emmerling ${ }^{57}$, whereas the total amount of plant-available $P$ remained constant in $0-25 \mathrm{~cm}$ depth. Vu et al. ${ }^{58}$ found a concentration of plant-available $P$ in $0-10 \mathrm{~cm}$ under NT. A high accumulation of $C_{\text {org }}$ was closely related to organic $\mathrm{P}$ dynamics, as organic $\mathrm{P}$ accumulates only when $\mathrm{C}$ availability is high ${ }^{59}$. Plantavailable $\mathrm{K}$ in the top layer was greater under RT, whereas there were no differences between RT and ploughed soil in $10-20 \mathrm{~cm}^{5}$.

\section{Nutrient budgets}

To ensure both short-term productivity and long-term sustainability, achieving a balance between inputs and outputs of nutrients within the farm system is crucial ${ }^{17}$. As nitrogen fixation by legumes was not considered in our calculation, nitrogen budgets were clearly negative for all treatments. The deficit was $-17 \mathrm{~kg} \mathrm{Nha}^{-1} \mathrm{yr}^{-1}$ in the mean of the CT compared to $-47 \mathrm{kgNha}^{-1} \mathrm{yr}^{-1}$ in the mean of the RT. P input and removal were balanced, while there was a surplus of $\mathrm{K}$ in all treatments over the first crop rotation period (Table 7 ). $\mathrm{K}$ surplus in the conventional treatment $\left(46 \mathrm{~kg} \mathrm{Kha}^{-1} \mathrm{yr}^{-1}\right)$ was twice that in the reduced treatment $\left(24 \mathrm{~kg} \mathrm{Kha}^{-1} \mathrm{yr}^{-1}\right)$. Removal of $\mathrm{N}$ and $\mathrm{K}$ under RT was higher, mainly due to the higher yields of grass-clover and silage maize ${ }^{27}$.

If biological $\mathrm{N}$-fixation was considered, $\mathrm{N}$-surpluses of up to $60 \mathrm{~kg} \mathrm{Nha}^{-1} \mathrm{yr}^{-118}$ could be estimated for organic farms in the UK. In a survey considering 88 European organically managed farms, Watson et al. ${ }^{17}$ found an average $\mathrm{N}$ surplus of $82 \mathrm{~kg} \mathrm{ha}^{-1} \mathrm{yr}^{-1}$ for dairy farms.

Stockless organic farms show P-deficits, while farms with livestock can compensate by importing $\mathrm{P}$ in additional feed and bedding material ${ }^{17,18}$. Negative balances of $\mathrm{P}$ for organic dairy farms in Norway were reported by Steinshamn et al. ${ }^{60}$. $\mathrm{P}$ deficits were also reported by Emmerling ${ }^{57}$ in a stockless trial with RT under organic farming conditions.

$\mathrm{K}$ budgets calculated for organic crop rotations show both surpluses and deficits ${ }^{17}$. Rotations with large return of manure had $\mathrm{K}$ surpluses or balanced $\mathrm{K}$ budgets, which is also the case in the present experiment.

To summarize, our results are in agreement with current data in the literature whereby stratification of $\mathrm{C}_{\text {org }}$, microbial biomass, microbial activity and soil nutrients were often observed after the adoption of RT. In the $10-20 \mathrm{~cm}$ soil layer, we found no differences in $\mathrm{C}_{\text {org }}$ and soil nutrients between the two tillage systems. Interestingly, soil microbial biomass $\mathrm{C}$ and microbial activity (DHA) were also higher in the untilled layer of RT. We found no similar results in the literature and assume that comparatively high inputs of organic material via crop rotation and manure were important factors in the present experiment. The goal of our current research is to target the role of soil types, and of clay minerals in particular, and especially the hydraulic dynamics and aeration of tillage systems. The results presented here reflect the situation after 6 years of RT under organic farming conditions. In their review, Kay and VandenBygaart ${ }^{3}$ found results of changes in $\mathrm{C}_{\mathrm{org}}$ obtained by different investigators to be most consistent when measurements were made more than 15 years after 
initiating the tillage trial. Further development of soil fertility indicators need to be assessed, also with respect to carbon sequestration in an organic farming system with diversified ley-based crop rotation and organic fertilization, as carbon sequestration of RT systems is still a matter of controversy ${ }^{8}$. Further research on the combined effects of organic farming and RT on this issue is necessary.

\section{Conclusions}

After the first 6-year crop rotation period, only tillage resulted in significant responses in soil fertility indicators. Hardly any effects of the fertilization treatments and the use of biodynamic preparations were observed. We found a strong stratification of $\mathrm{C}_{\mathrm{org}}$, microbial biomass, microbial activity (DHA) and soluble soil nutrients such as $\mathrm{P}$ and $\mathrm{K}$ in the RT tillage system. Enhancement of these properties in the superficial soil layer under RT, accompanied by $11 \%$ higher yields, led to the conclusion that RT is a suitable method for increasing soil fertility in organic farming systems. In conclusion, our RT system has demonstrated its capacity to provide a balanced performance with respect to several ecological services of agro-ecosystems, such as primary production, maintenance of soil fertility and natural resources, and nutrient supply ${ }^{61}$. It has to be pointed out that these results were obtained on a clayey soil and similar studies are needed under different pedo-climatic conditions. Moreover, because RT organic farming systems protect soil and improve nutrient use efficiency, they may be considered for agricultural policy support actions.

\begin{abstract}
Acknowledgements. We sincerely thank the farmers involved in the project, especially Pius Allemann, Rainer Sax and Daniel Böhler. For technical assistance, we are grateful to Robert Frei and Bruno Nietlispach (both FiBL, Frick). For help concerning statistics, we thank Franco Weibel (FiBL, Frick), Karl Moder and especially Ali Moghaddam (both BOKU, Vienna). We also thank Fredi Strasser for helpful discussions on RT under organic farming conditions and Monika Messmer for comments on the manuscript. This study was funded by the Swiss Federal Office for Agriculture and various foundations: Dutch BD-Vereniging (NL), Stiftung zur Pflege von Mensch, Mitwelt und Erde (CH), Sampo Verein $(\mathrm{CH})$, Software AG-Stiftung (DE) and Evidenzgesellschaft $(\mathrm{CH})$ and Coop Fond für Nachhaltigkeit $(\mathrm{CH})$.
\end{abstract}

\section{References}

1. Lal, R. 2009. Laws of sustainable soil management. Agronomy for Sustainable Development 29:7-9.

2. Pekrun, C. and Claupein, W. 1998. Forschung zur reduzierten Bodenbearbeitung in Mitteleuropa: Eine Literaturübersicht. Mitteilungen der Gesellschaft für Pflanzenbauwissenschaften 2:160-175.

3. Kay, B.D. and VandenBygaart, A.J. 2002. Conservation tillage and depth stratification of porosity and soil organic matter. Soil and Tillage Research 66:107-118.

4. Alvarez, R. 2005. A review of nitrogen fertilizer and conservation tillage effects on soil organic carbon storage. Soil Use and Management 21:38-52.
5. Rasmussen, K.J. 1999. Impact of ploughless soil tillage on yield and soil quality: A Scandinavian review. Soil and Tillage Research 53:3-14.

6. Kladivko, E.J. 2001. Tillage systems and soil ecology. Soil and Tillage Research 61:61-76.

7. Koch, H.-J. and Stockfisch, N. 2006. Loss of soil organic matter upon ploughing under a loess soil after several years of conservation tillage. Soil and Tillage Research 86:73-83.

8. Baker, J.M., Ochsner, T.E., Venterea, R.T., and Griffis, T.J. 2007. Tillage and soil carbon sequestration - what do we really know? Agriculture, Ecosystems and Environment 118:1-5.

9. Kandeler, E., Tscherko, D., and Spiegel, H. 1999. Long-term monitoring of microbial biomass, $\mathrm{N}$ mineralisation and enzyme activities of a chernozem under different tillage management. Biology and Fertility of Soils 28:343-351.

10. Peigné, J., Ball, B.C., Roger-Estrade, J., and David, C. 2007. Is conservation tillage suitable for organic farming? A review. Soil Use and Management 23:129-144.

11. FAO. 2003. Organic Agriculture. FAO Inter-Departmental Working Group on Organic Agriculture, Rome.

12. Fließbach, A., Oberholzer, H.-R., Gunst, L., and Mäder, P. 2007. Soil organic matter and biological soil quality indicators after 21 years of organic and conventional farming. Agriculture, Ecosystems and Environment 118:273-284.

13. Scheffer, F. and Schachtschabel, P. 2002. Lehrbuch der Bodenkunde. Spektrum Akademischer Verlag, Heidelberg, Berlin.

14. Munro, T.L., Cook, H.F., and Lee, H.C. 2002. Sustainability indicators used to compare properties of organic and conventionally managed topsoils. Biological Agriculture and Horticulture 20:201-214.

15. Drinkwater, L.E., Wagoner, P., and Sarrantonio, M. 1998. Legume-based cropping systems have reduced carbon and nitrogen losses. Nature 396:262-265.

16. Six, J., Frey, S.D., Thiet, R.K., and Batten, K.M. 2006. Bacterial and fungal contributions to carbon sequestration in agroecosystems. Soil Science Society of America Journal 70:555-569.

17. Watson, C.A., Bengtsson, H., Ebbesvik, M., Løes, A.-K., Myrbeck, A., Salomon, E., Schroder, J., and Stockdale, E.A. 2002. A review of farm-scale nutrient budgets for organic farms as a tool for management of soil fertility. Soil Use and Management 18:264-273.

18. Berry, P.M., Stockdale, E.A., Sylvester-Bradley, R., Philipps, L., Smith, K.A., Lord, E.I., Watson, C.A., and Fortune, S. 2003. N, P and K budgets for crop rotations on nine organic farms in the UK. Soil Use and Management 19:112-118.

19. IFOAM. 2006. IFOAM basic standards for organic crop production and processing. Version 2005. IFOAM, Germany.

20. Kainz, M., Gerl, G., Lemnitzer, B., Bauchenss, J., and Hülsbergen, K.-J. 2005. Effects of different tillage systems in the long-term field experiment Scheyern. In J. Hess and G. Rahmann (eds). 8. Wissenschaftstagung Ökologischer Landbau, Kassel, Germany. p. 1-4.

21. Schmidt, H., Schulz, F., and Leithold, G. 2006. Organic farming trial Gladbacherhof: Effects of different crop rotations and tillage systems. In J. Raupp, C. Pekrun, M. Oltmanns, and U. Koepke (eds). Long-term Field Experiments in Organic Farming. International Society of Organic Agriculture Research (ISOFAR). p. 165-182. 
22. Pekrun, C., Schneider, N., Wüst, C., Jauss, F., and Claupein, W. 2003. Einfluss reduzierter Bodenbearbeitung auf Ertragsbildung, Unkrautdynamik und Regenwurmpopulationen im Ökologischen Landbau. In B. Freyer (ed.). Beiträge zur 7. Wissenschaftstagung zum Ökologischen Landbau, Institut für Ökologischen Landbau, Wien, p. 21-24.

23. Hampl, U. 2005. Projekt Ökologischen Bodenbewirtschaftung. Zehn Jahre differenzierte Grundbodenbearbeitung im ökologischen Ackerbau. Abschlussbericht. Stiftung Ökologie and Landbau, Bad Dürkheim.

24. Schulz, F., Brock, C., and Leithold, G. 2008. Effects of Farm Type and Different Intensities of Soil Tillage on Cash Crop Yields and Soil Organic Matter, in Cultivating the Future Based on Science: 2nd Conference of the International Society of Organic Agriculture Research ISOFAR, June 18-20, 2008, Modena, Italy.

25. Emmerling, C. 2007. Reduced and conversation tillage effects on soil ecological properties in an organic farming system. Biological Agriculture and Horticulture 24:363-377.

26. Berner, A., Hildermann, I., Fliessbach, A., Pfiffner, L., Niggli, U., and Mäder, P. 2008. Crop yield and soil quality response to reduced tillage under organic management. Soil and Tillage Research 101:89-96.

27. Krauss, M., Berner, A., Burger, D., Wiemken, A., Niggli, U., and Mäder, P. 2010. Reduced tillage in temperate organic farming: implications for crop management and forage production. Soil Use and Management 26:12-20.

28. Zaller, J.G. and Köpke, U. 2004. Effects of traditional and biodynamic farmyard manure amendment on yields, soil chemical, biochemical and biological properties in a long-term experiment. Biology and Fertility of Soils 40:222-229.

29. Carpenter-Boggs, L., Kennedy, A.C., and Reganold, J.P. 2000. Organic and Biodynamic Management: effects on Soil Biology. Soil Science Society American Journal 64:16511659.

30. FAL, FAW and RAC. 1996. Referenzmethoden der Eidg. landwirtschaftlichen Forschungsanstalten-1. Bodenuntersuchung zur Düngeberatung., Ed, Zürich-Reckenholz.

31. Vance, E.D., Brookes, P.C., and Jenkinson, D.S. 1987. An extraction method for measuring soil microbial biomass $\mathrm{C}$. Soil Biology and Biochemistry 19:703-707.

32. Joergensen, R.G. and Mueller, T. 1996. The fumigation extraction method to estimate soil microbial biomass: Calibration of the $k_{\mathrm{EC}}$-factor. Soil Biology and Biochemistry 28:25-31.

33. Joergensen, R.G. and Mueller, T. 1996. The fumigation extraction method to estimate soil microbial biomass: calibration of the $k_{\mathrm{EN}}$-factor. Soil Biology and Biochemistry 28:33-37.

34. Tabatabai, M.A. 1982. Soil enzymes. In A.L. Page, R.H. Miller, and D.R. Keeney (eds). Methods of Soil Analysis, Part 2: Chemical and Microbiological Properties. Soil Science Society of America, Madison, WI. p. 903-947.

35. Pronin, D. Einfluss unterschiedlicher Bearbeitungs- und Bestellverfahren auf die vertikale Differenzierung von Bodenkennwerten auf lehmigem Sand (Brandenburg) und Schwarzerde (Novosibirsk) sowie auf ausgewählte Pflanzenmerkmale. Shaker Verlag, Aachen, Germany.

36. Friedel, J.K., Munch, J.C., and Fischer, W.R. 1996. Soil microbial properties and the assessment of available soil organic matter in a haplic Luvisol after several years of different cultivation and crop rotation. Soil Biology and Biochemistry 28:479-488.

37. Ogle, S.M., Breidt, F.J., and Paustian, K. 2005. Agricultural management impacts on soil organic carbon storage under moist and dry climatic conditions of temperate and tropical regions. Biogeochemistry 72:87-121.

38. Stockfisch, N., Forstreuter, T., and Ehlers, W. 1999. Ploughing effects on soil organic matter after twenty years of conservation tillage in Lower Saxony, Germany. Soil and Tillage Research 52:91-101.

39. Angers, D.A., Bolinder, M.A., Carter, M.R., Gregorich, E.G., Drury, D.F., Liang, B.C., Voroney, R.P., Simard, R.R., Donald, R.G., Beyaert, R.P., and Martel, J. 1997. Impact of tillage practies on organic carbon and nitrogen storage in cool humid soils of eastern Canada. Soil and Tillage Research 41:191-201.

40. Angers, D.A., N'dayegamiye, A., and Côté, D. 1993. Tillageinduced differences in organic matter of particle-size fractions and microbial biomass. Soil Science Society of America Journal 57:512-516.

41. Kouwenhoven, J.K. and Boer, J. 1997. Exoploughing for sustainable and organic farming. In M. Fortyma (ed.). 14th Conference of the International Soil Tillage Research Organization (ISTRO), July 27 to August 1, Pulawy, Poland. p. 339-401.

42. Drinkwater, L.E., Janke, R.R., and Rossoni-Longnecker, L. 2000. Effects of tillage intensity on nitrogen dynamics and productivity in legume-based grain systems. Plant and Soil 227:99-113.

43. Conant, R.T., Easter, M., Paustian, K., Swan, A., and Williams, S. 2007. Impacts of periodic tillage on soil C stocks: A synthesis. Soil and Tillage Research 95:1-10.

44. Pierce, F.J., Fortin, M.-C., and Staton, M.J. 1994. Periodic plowing effects on soil properties in a no-till farming system. Soil Science Society of America Journal 58:1782-1787.

45. Kettler, T.A., Lyon, D.J., Doran, J.W., Powers, W.L., and Stroup, W.W. 2000. Soil quality assessment after weedcontrol tillage in a no-till wheat-fallow cropping system. Soil Science Society of America Journal 64:339-346.

46. Grandy, A.S. and Robertson, G.P. 2006. Aggregation and organic matter protection following tillage of a previously uncultivated soil. Soil Science Society of America Journal 70:1398-1406.

47. Franzluebbers, A.J. and Stuedemann, J.A. 2008. Early response of soil organic fractions to tillage and integrated crop-livestock production. Soil Science Society of America Journal 72:613-625.

48. Christensen, B.T. 1988. Effects of animal manure and mineral fertilizer on the total carbon and nitrogen contents of soil size fractions. Biology and Fertility of Soils 5:304307.

49. Wander, M.M. and Traina, S.J. 1996. Organic matter fractions from organically and conventionally managed soils. 1. Carbon and nitrogen distribution. Soil Science Society of America Journal 60:1081-1087.

50. Sparling, G.P. 1992. Ratio of microbial biomass carbon to soil organic-carbon as a sensitive indicator of changes in soil organic-matter. Australian Journal of Soil Research 30:195-207.

51. Alvarez, R., Diaz, R.A., Barbero, N., Santanatoglia, O.J., and Blotta, L. 1995. Soil organic-carbon, microbial biomass 
and $\mathrm{CO}_{2}-\mathrm{C}$ production from three tillage systems. Soil and Tillage Research 33:17-28.

52. von Lützow, M., Leifeld, J., Kainz, M., Kögel-Knabner, I., and Munch, J.C. 2002. Indications for soil organic matter quality in soils under different management. Geoderma 105:243-258.

53. Franzluebbers, A.J. and Brock, B.G. 2007. Surface soil responses to silage cropping intensity on a Typic Kanhapludult in the piedmont of North Carolina. Soil and Tillage Research 93:126-137.

54. Heinze, S., Raupp, J. and Joergensen, R.G. 2010. Effects of fertilizer and spatial heterogeneity in soil $\mathrm{pH}$ on microbial biomass indices in a long-term field trial of organic agriculture. Plant and Soil 328:203-215.

55. Joergensen, R.G. 1995. Die quantitative Bestimmung der mikrobiellen Biomasse in Böden mit der ChloroformFumigations-Extraktions-Methode. Institut für Bodenwissenschaften, Universität Göttingen, Göttingen.

56. Guggenberger, G., Frey, S.D., Six, J., Paustian, K., and Elliott, E.T. 1999. Bacterial and fungal cell-wall residues in conventional and no-tillage agroecosystems. Soil Science Society American Journal 63:1188-1198.
57. Emmerling, C. 2005. Entwicklung der organischen Bodensubstanz, Bodenstruktur, Nährstoffgehalte sowie bodenbiologischen Eigenschaften, Abschlussbericht Projekt Ökologische Bodenbewirtschaftung. Stiftung Ökologie und Landbau, Bad Dürkheim, Germany.

58. Vu, D.T., Tang, C., and Armstrong, R.D. 2009. Tillage system affects phosphorus form and depth distribution in three contrasting Victorian soils. Australian Journal of Soil Research 47:33-45.

59. Bünemann, E.K., Heenan, D.P., Marschner, P., and McNeill, A.M. 2006. Long-term effects of crop rotation, stubble management and tillage on soil phosphorus dynamics. Australian Journal of Soil Research 44:611-618.

60. Steinshamn, H., Thuen, E., Bleken, M.A., Brenøe, U.T., Ekerholt, G., and Yri, C. 2004. Utilization of nitrogen (N) and phosphorus (P) in an organic dairy farming system in Norway. Agriculture, Ecosystems and Environment 104:509-522.

61. Björklund, J., Limburg, K.E., and Rydberg, T. 1999. Impact of production intensity on the ability of the agricultural landscape to generate ecosystem services: an example from Sweden. Ecological Economics 29:269-291. 